\title{
An Empirical Study on Environmental Accounting Information Disclosure of Manufacturing Enterprises in China
}

\author{
Shuang Tang \\ Jianghan University \\ Wuhan, China
}

\author{
Yihong Xu \\ Jianghan University \\ Wuhan, China
}

\begin{abstract}
With the advent of the low-carbon economy, people's awareness of environmental protection and relevant concept have gradually increased. China's environmental problems have been paid more extensive attention. China's manufacturing enterprises are the driving force and the backbone of economic construction and development. Therefore, China's modern manufacturing enterprises can not shirk the social responsibility of environmental protection. China's environmental pollution, ecological damage and other issues are increasing daily. Manufacturing enterprises are suggested to strictly abide by the development of environmental protection for the legislative requirements and environmental management standards to assume the corporate social and environmental responsibility, promoting China's low-carbon recycling economy. This paper chooses the representative company data of 210 Shanghai manufacturing enterprises from 2000 to 2016 as the research sample, making a linear regression analysis on the general situation of environmental accounting information disclosure of manufacturing enterprises in China. It realizes the real information disclosure of environmental accounting information of manufacturing enterprises in China, focusing on the status quo and the existing problems. The paper finally combines with the analysis results for China's manufacturing enterprises environmental accounting information disclosure of the main issues and puts forward a policy of reasonable recommendations.
\end{abstract}

Keywords-Manufacturing Enterprises; Environmental Accounting Information Disclosure; Status and Problems; Empirical Research; Management

\section{INTRODUCTION}

In recent years, China's environmental problems are increasingly serious and has seriously threatened people's normal work and life. As China's urgent problems, environmental issues are needed to be resolved by the government, causing overall concern from enterprises and the general public. In the moment of environmental problems continue heating up, people's traditional values for the enterprise has also changed. People's social expectations for the enterprise is no longer just to solve the employment, create economic benefits and support the national economic construction. As a contrast, people are willing to take the initiative to bear from the necessary social responsibility, and they are willing to contribute to the social forces of enterprises for the protection of the environment and ecological health.

For the manufacturing industry, its production and operation activities will have a certain impact on the environment to some extent. Enterprise manufacturing and production processes are the main source of environmental pollutants. Therefore, as China's important basis for economic development, manufacturing is core for the protection of the environment and the effective management of environmental problems which bear a significant social responsibility. In the pursuit of economic interests and in the pursuit of maximization, manufacturing industries, at the same time, should spend more time focusing on environmental pollution and damage, taking the initiative to assume the social and environmental responsibility so that the enterprise itself. Then, the common environmental society can achieve sustainable long-term development.

II. AN ANALYSis OF THE PRESENT SitUATION OF ENVIRONMENTAL ACCOUNTING INFORMATION DISCLOSURE OF MANUFACTURING COMPANIES IN CHINA

In this paper, we selected the data of the listed manufacturing industry from the Shanghai Stock Exchange. We sort out the data and screening out of financial accounting information incomplete A-share listed companies Finally, we complete the size of data manufacturing company as 210. Finally, 210 Shanghai Stock Exchange manufacturing companies in 2013 environmental accounting information disclosure index have been determined as the sample data for the empirical study of this paper. (All data are available from the Shanghai Securities Exchange website, the Financial Data Service Network and the Annual Report of the Companies in 2013, the Financial Statements and the Social Responsibility Report).

According to the data, we will classify the 210 listed manufacturing companies according to the different categories of the main manufacturing products, which are classified into different research categories with different environmental pollution levels. The specific environmental disclosure levels are as "Table I". 
TABLE I. ANALYSIS ON PRESENT SitUATION OF ENVIRONMENTAL ACCOUNTING INFORMATION DISCLOSURE IN VARIOUS INDUSTRIES

\begin{tabular}{|c|c|c|c|}
\hline & Industry & $\begin{array}{c}\text { Sample } \\
\text { Size }\end{array}$ & $\begin{array}{c}\text { Means of } \\
\text { Environmental } \\
\text { Disclosure }\end{array}$ \\
\hline \multirow{6}{*}{$\begin{array}{l}\text { Heavily } \\
\text { Polluting } \\
\text { Industries }\end{array}$} & Textile Industry & 24 & 6.554 \\
\hline & $\begin{array}{l}\text { Metal and Nonmetallic } \\
\text { Industries }\end{array}$ & 45 & 10.125 \\
\hline & $\begin{array}{l}\text { Biological, Chemical, } \\
\text { Pharmaceutical Industry }\end{array}$ & 30 & 8.331 \\
\hline & Plastic Industry & 35 & 9.107 \\
\hline & $\begin{array}{l}\text { Food, Beverage, } \\
\text { Processing Industry }\end{array}$ & 30 & 6.227 \\
\hline & Subtotal & 164 & 7.724 \\
\hline \multirow{4}{*}{$\begin{array}{l}\text { Non-heavy } \\
\text { Polluting } \\
\text { Industries }\end{array}$} & $\begin{array}{l}\text { Machinery and } \\
\text { Electronics Industry }\end{array}$ & 29 & 8.521 \\
\hline & $\begin{array}{l}\text { Furniture Decoration } \\
\text { Industry }\end{array}$ & 17 & 3.229 \\
\hline & Subtotal & 46 & 4.751 \\
\hline & Total & 210 & 7.609 \\
\hline
\end{tabular}

As shown in the table above, the average value of the environmental profile of the sample data company is 6.554 , The average environmental disclosure index is 0.319 , indicating that the overall level of disclosure is not high. The average level of environmental accounting information disclosure between different industry categories is different. The metal and non-metallic manufacturing enterprises environmental accounting information disclosure level lead the entire manufacturing industry. Their average disclosure EDI is up to 10.125 which is far more than the home decoration industry 3.229. The reason is the particularity of the metal and non-metallic manufacturing industry that must be more detailed and clear environmental accounting information disclosure. Another reason is the whole community; it has began to pay more attention to environmental protection series problems.

\section{AN EMPIRICAL ANALYSIS ON THE INFLUENCING} FACTORS OF ENVIRONMENTAL ACCOUNTING INFORMATION DISCLOSURE IN MANUFACTURING INDUSTRY IN CHINA

\section{A. Research Hypothesis}

The main contents of this paper are the present situation and existing problems of environmental accounting information disclosure in manufacturing industries. Therefore, according to the specific situation and industry characteristics of manufacturing industry, this paper mainly makes the following six research hypothesis:

- Hypothesis 1: the size of the company is positively correlated with the level of environmental accounting information disclosure;

- Hypothesis 2: the performance of the company is positively related to the level of environmental accounting information disclosure.

- Hypothesis 3: the degree of corporate liability is positively correlated with the level of environmental accounting information disclosure;

- Hypothesis 4: the nature of the company's equity is positively correlated with the level of environmental accounting information disclosure;
- Hypothesis 5: the company's equity concentration is positively correlated with the level of environmental accounting information disclosure;

- Hypothesis 6: the corporate social responsibility report is positively related to the level of environmental accounting information disclosure.

\section{B. Research Variables and Model Construction}

1) Research Design Explained Variable: The main explanatory variable of this paper is the environmental accounting information disclosure index of 210 listed manufacturing companies. Through the division of the three levels, this paper specifically carries out the calculation of EDI with respect to the level of indicators and secondary indicators to give different weight. More accurate manufacturing industry listed companies weighted summary of the company's environmental accounting information disclosure of specific EDI Value, being the main explanatory variable in this paper.

2) Research Design Explanatory Variables: According to the hypothesis, we make a series of influence assumptions about the disclosure of environmental accounting information. The main factors of these effects are the main explanatory variables of empirical research: 1 . SIZE: the indicators that can represent the size of the company are the company's market value, total assets and sales revenue. In this paper, the basic principles of effective use of data have been taken into account. The total amount of assets listed companies are selected to reflect the natural number of the company's size; 2. Listed company performance (ROE): the company's performance is the company's financial performance results. We select the return on net assets as a specific consideration, is the most comprehensive financial indicators; 3 . LEV of listed companies: scholars in the study of corporate debt performance when the general use of asset-liability ratio and the ratio of property rights to measure and reflect the degree of debt of listed companies. This paper selects asset-liability ratio as a specific indicator of the study; 4. Equity nature (GA): most of the manufacturing enterprises listed in China are state-owned holdings, and the private enterprises are required to be supervised and managed by the state-owned shares. Therefore, this paper selects the shareholders of the company to represent the state investment of the total number of shares held by the organization or department. 5 . HERF: In the measurement of the concentration of listed companies when the general foreign scholars will use the Herfindel index. 6.Social Responsibility Disclosure Report (SB): Social Responsibility Report, this indicator is a clear qualitative indicator. The paper uses the dummy variable approach to quantify it, that is, if the listed company publishes a social responsibility report, its record is 1 , otherwise, the record is 0 .

3) Model Construction: In this paper, descriptive statistics and multiple linear regression analysis are used to 
study the influencing factors of environmental accounting information disclosure of listed companies in China. Based on the hypothesis, a linear regression model was established which is shown as below:

$\mathrm{EDI}=\beta_{0}+\beta_{1} \mathrm{SIZE}+\beta_{2} \mathrm{ROE}+\beta_{3} \mathrm{LEV}+\beta_{4} \mathrm{GA}+\beta_{5} \mathrm{HERF}+\beta_{6} \mathrm{SB}+\mu$

\section{Empirical Analysis and Explanation}

1) Descriptive Statistical Analysis: Based on the environmental accounting information disclosure project and the scoring principle set up in this paper. We select and index the independent environmental report of 210 listed manufacturing companies in 2016 and finally obtained the environmental accounting information disclosure project which the descriptive statistics for the project are as "Table II".

TABLE II. COMPANy EN VIRONMENTAL ACCOUNTING INFORMATION DisClOSURE ProJeCt SCORING TABLE

\begin{tabular}{|c|c|c|c|c|c|}
\hline $\begin{array}{l}\text { Project } \\
\text { Category }\end{array}$ & Specific Disclosure Items & $\begin{array}{c}\text { Number of } \\
\text { Disclosed } \\
\text { Companies }\end{array}$ & $\begin{array}{l}\text { Total } \\
\text { Score }\end{array}$ & Average & $\begin{array}{c}\text { The } \\
\text { Overall } \\
\text { Mean }\end{array}$ \\
\hline \multirow[t]{5}{*}{$\begin{array}{l}\text { The Accuracy of } \\
\text { The Information }\end{array}$} & Environmental Protection Facilities, Technology, Content Investment & 56 & 73 & 1.04 & 1.16 \\
\hline & Capital of the Current Environmental Measures of Capital Projects & 134 & 167 & 1.21 & \\
\hline & The Greening Situation of the Enterprise & 120 & 131 & 1.05 & \\
\hline & $\begin{array}{l}\text { Cost of Enterprises for Environmental Management and Pollution } \\
\text { Treatment }\end{array}$ & 156 & 184 & 1.18 & \\
\hline & The Financial Statements of the Enterprise for Environmental Content & 148 & 178 & 1.20 & \\
\hline \multirow[t]{4}{*}{$\begin{array}{l}\text { The Breadth of } \\
\text { Information }\end{array}$} & $\begin{array}{l}\text { The relevant data description about whether or not the enterprise is able } \\
\text { to establish environmental protection departments }\end{array}$ & 132 & 160 & 1.03 & 1.02 \\
\hline & Compliance of Laws and Regulations on Corporate Environment & 59 & 62 & 1.05 & \\
\hline & The Treatment of Waste Disposal & 84 & 84 & 1.00 & \\
\hline & $\begin{array}{l}\text { Pollution Prevention and Control of Enterprises for the Basic } \\
\text { Expenditure }\end{array}$ & 32 & 37 & 1.15 & \\
\hline \multirow[t]{2}{*}{$\begin{array}{c}\text { The Standard of } \\
\text { Information }\end{array}$} & $\begin{array}{l}\text { Whether or not the Enterprise Conforms to ISO14001 Environmental } \\
\text { Certification }\end{array}$ & 165 & 195 & 1.31 & 1.22 \\
\hline & Other Information Related to Corporate Environmental Issues & 124 & 141 & 1.09 & \\
\hline
\end{tabular}

As shown above, it can be seen that a comprehensive evaluation of the accuracy of the information is in the score of 1.16. Although the sample companies overall performance is not good, it broadly in line meets the requirements, especially for the aspects such as capital expenditures for the current business, environmental protection measures aspects of sewage charges, environmental management and pollution prevention spending. Manufacturing companies responsibility is clear. The task is very clear: both disclose a specific contribution which announced their own business in the past year on the environment made in environmental accounting information and should bear social responsibility. Comprehensive evaluation in terms of the breadth of information score is 1.02 . The sample enterprises this part of the environmental accounting information disclosure is not good. The breadth and scope have failed to disclose the details of specific social requirements, corporate or environmental liabilities, environmental aspects of funding and subsidies, tax breaks and other waste income and don't do much detailed disclosure of the number of enterprises, after this part. The environmental accounting information content level of disclosure should be strengthened; comprehensive evaluation of the information in the standard terms is within a score of 1.22. This part of the environment accounting information content sample business has shown better results, which most enterprises have achieved a clear disclosure of information. Explanation of the basis for the mandate of the enterprises majority has done well to comply.

2) Multiple Linear Regression Analysis: We carry out multiple linear regression analysis on the basic model of the variable construction, bringing all the explanatory variables into the model to calculate the results as shown in the following list:

TABLE III. PARAMETERS FOR MULTIPLE LINEAR REGRESSION

\begin{tabular}{|c|c|c|c|c|c|}
\hline $\begin{array}{c}\text { Sample } \\
\text { Size }\end{array}$ & $\mathbf{R}$ & $\mathbf{R}^{\mathbf{2}}$ & $\begin{array}{c}\text { Adjustment } \\
\mathbf{R}^{\mathbf{2}}\end{array}$ & $\begin{array}{c}\text { Standard } \\
\text { Error }\end{array}$ & $\begin{array}{c}\text { Durbin- } \\
\text { Waston }\end{array}$ \\
\hline 210 & 0.399 & 0.326 & 0.322 & 0.68831 & 1.447 \\
\hline
\end{tabular}

TABLE IV. REGRESSION COEFFICIENT AND SigNIFICANCE CHECKLIST

\begin{tabular}{|l|l|l|l|l|l|}
\hline \multirow{2}{*}{ Variables } & \multicolumn{2}{|c|}{ Nonstandard Coefficient } & $\begin{array}{c}\text { Standard } \\
\text { Coefficient }\end{array}$ & \multirow{2}{*}{ t } & \multirow{2}{*}{ Sig. } \\
\cline { 2 - 4 } $\begin{array}{c}\text { (Consta } \\
\text { nt) }\end{array}$ & -59.125 & 6.952 & & \multicolumn{1}{|c|}{ Standard Error } & \\
\hline SIZE & 2.950 & 0.280 & 0.052 & 3.220 & 0.000 \\
\hline ROE & 1.762 & 2.147 & 0.065 & 4.120 & 0.005 \\
\hline LEV & -4.116 & 1.994 & -0.069 & 2.170 & 0.019 \\
\hline GA & 2.054 & 3.121 & 0.183 & 0.940 & 0.002 \\
\hline HERF & 0.054 & 0.942 & 0.145 & 0.660 & 0.184 \\
\hline SB & 0.980 & 0.045 & 0.226 & 3.320 & 0.061 \\
\hline
\end{tabular}

As shown in "Table III", the overall situation of the regression is shown. The fitting degree of the model is 0.326 , the adjusted goodness is 0.322 . The DW value is 1.694 which is close to 2 . The overall effect of the equation is obvious and the fitting degree is good. As shown in the 
Table 6, the $\mathrm{F}$ test value of the model is 35.693 . The significance probability is 0.000 , which is significant at the significant level of $\mathrm{P}=1 \%$, indicating that the regression effect is very good, and the model is statistically significant. As shown in "Table IV", at the significant level of $\mathrm{P}=5 \%$, the size of the company, the company's performance, corporate debt capacity and the nature of equity and other indicators have passed a significant test with significant impact. Therefore, we can see that the scale of the company, the company's performance, the company's debt capacity, the nature of equity and other indicators for environmental accounting information disclosure of the impact of a stronger capacity. The size of the company compare the results of the most significant impact, the direct impact disclosure of Environmental Accounting Information.

The specific regression equation is:

$$
\begin{gathered}
\mathrm{EDI}=-59.125+2.95 \mathrm{SIZE}+1.762 \mathrm{ROE}-4.116 \mathrm{LEV}+2.054 \mathrm{GA} \\
+0.054 \mathrm{HERF}+0.980 \mathrm{SB}
\end{gathered}
$$

According to the formula, it can be seen that, in addition to the degree of debt with the disclosure of environmental accounting information which has a negative correlation level of the accident, the remaining variables are consistent with the assumptions. It is clear that the size of the company and the impact of environmental accounting information disclosure are the most significant, followed by the nature of equity. Once again, the company's performance, although the rest of the indicators have a positive impact, effect is not significant.

\section{CONCLUSION}

In this paper, the relevant data of listed companies in Shanghai manufacturing industry from 2000 to 2010 are selected as the research samples, and the empirical analysis model is constructed to analyze the influencing factors of environmental accounting information disclosure of listed companies in China. The following conclusions are drawn:

- The overall quality of China's environmental accounting information disclosure is low although there are differences with respect to the level of information disclosure in different industries of manufacturing industry. The overall performance of heavily polluting industries to disclose the degree is relatively weak and most of the company's disclosure to descriptive information-based. There is very few quantitative data disclosure of information that implies that the degree of environmental response is quite limited.

- Through regression analysis, it can be seen that there is a significant positive correlation between the size of the listed company and the level of environmental accounting information. That is, the greater the scale of manufacturing listed companies is, the higher the degree of environmental accounting information disclosure will be; there is a significant positive correlation between the performance of listed companies and the degree of environmental accounting information disclosure. That is, the better the performance of listed companies in the manufacturing industry is, the higher the degree of environmental accounting information disclosure will occur; manufacturing industry debt ratio and environmental accounting information disclosure significantly negative correlation. This means, the higher the level of debt accounting of listed companies is, the lower the degree of environmental accounting information disclosure is. The nature of equity ownership of manufacturing listed companies and environmental accounting information disclosure level is not significant, but there is a certain positive relationship between the two. The disclosure status of environmental accounting information is positively correlated with the degree of equity concentration of manufacturing listed companies. That is, the more the nature of the equity of listed companies in manufacturing industry is more concentrated, and the environmental accounting information disclosure is relatively high. The higher the degree of environmental accounting information disclosure system. There is no significant correlation between the social responsibility report and the level of environmental accounting information disclosure, but it also has a certain positive explanatory relationship. That is, the more detailed social responsibility disclosure report is, the higher the degree of environmental accounting information disclosure will be.

\section{REFERENCES}

[1] Fekrat, Inclan C, Petroni D. Corporate environmental disclo-sure: competitive disclosure hypothesis using 1991 annualreport data [J]. The international Journal of accounting, 1996 (1): 175-195.

[2] Buhr N. A structuration view on the initiation of environmental reports [J]. Critical Perspective on Accounting, 2002 (2): 17-38.

[3] Raphaël M, George R, Frank G. Transcription in four dimensions: nuclear receptor-directed initiation of gene expression [J]. Embo Reports, 2006, 7(2):161-167.

[4] Christine Jasch. The Use of Environmental Management Accounting(EMA)for identifying environmental costs [J]. Journal of Cleaner Production, 2003, (6): 59--65.

[5] Jeffery Everett. Exploring (false) dualisms for environmental accounting praxis [J]. Critical Perspectives on Accounting, 2004, (1 5): $1061-1084$.

[6] J. Mylonakis, P. Tahinakis. The use of accounting information systems in the evaluation onenvironmental costs: a cost benefit analysis model proposal $[\mathrm{J}]$. International Journal of Energy Research, 2006, (1 I): 103-1 10 .

[7] Junrui Zhang, Huiting Guo, Bin Li. The influence of financial situation on environmental information disclosure in China's chemical industry $[\mathrm{J}]$. International Journal of Global Environmental Issues, 2009, (3): $33 \sim 39$. 